\title{
High Prevalence of Hepatitis C Infection Among Adult Patients at Four Urban Emergency Departments - Birmingham, Oakland, Baltimore, and Boston, 2015-2017
}

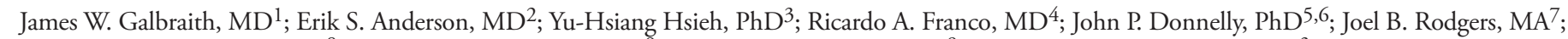
Elissa M. Schechter-Perkins, $\mathrm{MD}^{8}$; William W. Thompson, PhD ${ }^{9}$; Noele P. Nelson, MD, PhD ${ }^{9}$; Richard E. Rothman, MD, PhD ${ }^{3}$; Douglas A.E. White, MD ${ }^{2}$

Identifying persons with hepatitis $\mathrm{C}$ virus (HCV) infection has become an urgent public health challenge because of increasing HCV-related morbidity and mortality, low rates of awareness among infected persons, and the advent of curative therapies (1). Since 2012, CDC has recommended testing of all persons born during 1945-1965 (baby boomers) for identification of chronic HCV infection (1); urban emergency departments (EDs) are well positioned venues for detecting HCV infection among these persons. The United States has witnessed an unprecedented opioid overdose epidemic since 2013 that derives primarily from commonly injected illicit opioids (e.g., heroin and fentanyl) (2). This injection drug use behavior has led to an increase in HCV infections among persons who inject drugs and heightened concern about increases in human immunodeficiency virus (HIV) and HCV infection within communities disproportionately affected by the opioid crisis $(3,4)$. However, targeted strategies for identifying HCV infection among persons who inject drugs is challenging (5,6). During 2015-2016, EDs at the University of Alabama at Birmingham; Highland Hospital, Oakland, California; Johns Hopkins Hospital, Baltimore, Maryland; and Boston University Medical Center, Massachusetts, adopted opt-out (i.e., patients can implicitly accept or explicitly decline testing), universal hepatitis $\mathrm{C}$ screening for all adult patients. ED staff members offered HCV antibody (anti-HCV) screening to patients who were unaware of their status.* During similar observation periods at each site, ED staff members tested 14,252 patients and identified an overall $9.2 \%$ prevalence of positive results for anti-HCV among the adult patient

\footnotetext{
${ }^{*}$ To reduce potential duplicate testing of patients, sites utilized electronic health record mechanisms to identify and cancel HCV antibody orders on persons with prior $\mathrm{HCV}$ antibody testing in the last year, as well as any prior positive anti-HCV or RNA result.
}

population. Among the 1945-1965 birth cohort, prevalence of positive results for anti-HCV (13.9\%) was significantly higher among non-Hispanic blacks (blacks) (16.0\%) than among

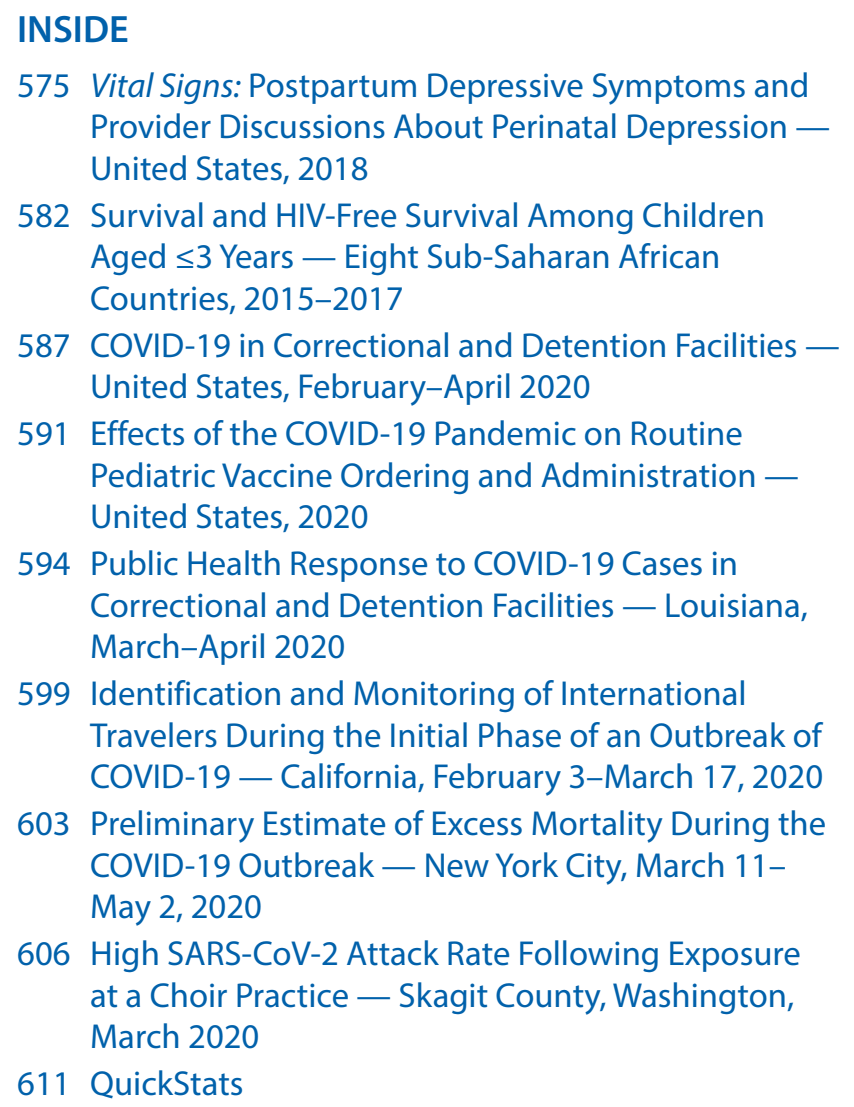

575 Vital Signs: Postpartum Depressive Symptoms and Provider Discussions About Perinatal Depression United States, 2018

582 Survival and HIV-Free Survival Among Children Aged $\leq 3$ Years - Eight Sub-Saharan African Countries, 2015-2017

587 COVID-19 in Correctional and Detention Facilities United States, February-April 2020

591 Effects of the COVID-19 Pandemic on Routine Pediatric Vaccine Ordering and Administration United States, 2020

594 Public Health Response to COVID-19 Cases in Correctional and Detention Facilities — Louisiana, March-April 2020

599 Identification and Monitoring of International Travelers During the Initial Phase of an Outbreak of COVID-19 - California, February 3-March 17, 2020

603 Preliminary Estimate of Excess Mortality During the COVID-19 Outbreak - New York City, March 11May 2, 2020

606 High SARS-CoV-2 Attack Rate Following Exposure at a Choir Practice - Skagit County, Washington, March 2020

611 QuickStats

Continuing Education examination available at https://www.cdc.gov/mmwr/mmwr_continuingEducation.html

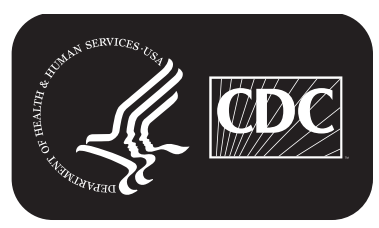

U.S. Department of Health and Human Services Centers for Disease Control and Prevention 
non-Hispanic whites (whites) $(12.2 \%)(\mathrm{p}<0.001)$. Among persons born after 1965, overall prevalence of positive results for anti-HCV was $6.7 \%$ and was significantly higher among whites $(15.3 \%)$ than among blacks $(3.2 \%)(\mathrm{p}<0.001)$. These findings highlight age-associated differences in racial/ethnic prevalences and the potential for ED venues and opt-out, universal testing strategies to improve $\mathrm{HCV}$ infection awareness and surveillance for hard-to-reach populations. This opt-out, universal testing approach is supported by new recommendations for hepatitis $\mathrm{C}$ screening at least once in a lifetime for all adults aged $\geq 18$ years, except in settings where the prevalence of positive results for $\mathrm{HCV}$ infection is $<0.1 \%$ ( 7 ).

A retrospective study from four urban academic EDs located in Birmingham, Alabama; Oakland, California; Boston, Massachusetts; and Baltimore, Maryland was conducted with approval from each institution's local Institutional Review Board. Each ED implemented opt-out, universal hepatitis C testing at different times and using differing methodologies among patients who reported no history of $\mathrm{HCV}$ infection. The period of observation for this study was 4 months, starting 1 month after initial implementation of opt-out, universal hepatitis $\mathrm{C}$ screening. Because of programmatic changes during the observation period at Johns Hopkins ED, only 3 months of observation is reported. All sites used the Abbott Architect anti-HCV assay (Abbott Diagnostics) for testing, with results available during the ED visit, and reflex HCV RNA testing performed on specimens collected during the ED encounter from persons with anti-HCV positive results. Each site used dedicated linkage-to-care coordinators to deliver positive test results and facilitate referral to $\mathrm{HCV}$ infection care.

$\mathrm{ED}$ sites collected cumulative hepatitis $\mathrm{C}$ testing outcomes for the 4-month study period, including cumulative anti-HCV results stratified by birth year, race/ethnicity, sex, and insurance type. Deidentified data were collected for aggregation and analysis at the University of Alabama at Birmingham site. Patient characteristics and prevalence estimates for positive results for anti-HCV were reported with $95 \%$ confidence intervals across sites. P-values $<0.05$ were considered statistically significant. STATA (version 15.1; StataCorp) was used to conduct all statistical analyses.

Using opt-out, universal hepatitis C screening (Table 1), EDs performed a total of 14,252 tests on unique visitors, and $1,315(9.2 \%)$ had positive test results for anti-HCV (Table 2). HCV RNA testing for current infection was performed for $1,118(85 \%)$ visitors with positive test results for anti-HCV, and 693 (62\%) of these persons had positive HCV RNA test results, indicating current $\mathrm{HCV}$ infection. The prevalence of positive results for anti-HCV was higher among persons in the 1945-1965 birth cohort (13.9\%) than among those in the cohort born after 1965 (6.7\%); however, the younger cohort accounted for $47.8 \%(628$ of 1,315$)$ of total cases reactive to anti-HCV identified.

Significant differences in positive results for anti-HCV by birth cohort and race/ethnicity were identified (Table 3). Among persons born during 1945-1965, overall positive results for anti-HCV prevalence was significantly higher among

The MMWR series of publications is published by the Center for Surveillance, Epidemiology, and Laboratory Services, Centers for Disease Control and Prevention (CDC), U.S. Department of Health and Human Services, Atlanta, GA 30329-4027.

Suggested citation: [Author names; first three, then et al., if more than six.] [Report title]. MMWR Morb Mortal Wkly Rep 2020;69:[inclusive page numbers].

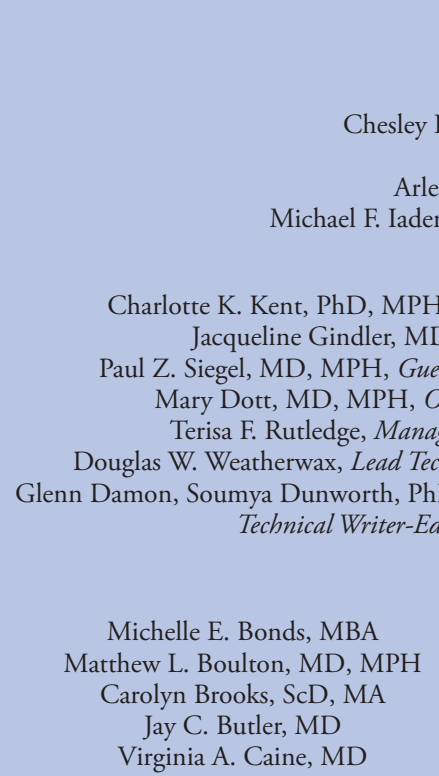

Centers for Disease Control and Prevention

Robert R. Redfield, MD, Director

Anne Schuchat, MD, Principal Deputy Director

s, MD, MPH, Deputy Director for Public Health Science and Surveillance

Rebecca Bunnell, PhD, MEd, Director, Office of Science

Arlene Greenspan, $\mathrm{PhD}$, Acting Director, Office of Science Quality, Office of Science

MMWR Editorial and Production Staff (Weekly)
Charlotte K. Kent, PhD, MPH, Editor in Chief

Jacqueline Gindler, MD, Editor

Trical Writer-Editor ya Dunworth, PhD, Teresa M. Hood, MS,

MMWR Editorial Board

Timothy F. Jones, MD, Chairman

Katherine Lyon Daniel, PhD

Jonathan E. Fielding, MD, MPH, MBA

David W. Fleming, MD

William E. Halperin, MD, DrPH, MPH

Jewel Mullen, MD, MPH, MPA

Jeff Niederdeppe, $\mathrm{PhD}$
Martha F. Boyd, Lead Visual Information Specialist

Maureen A. Leahy, Julia C. Martinroe, Stephen R. Spriggs, Tong Yang, Visual Information Specialists

Quang M. Doan, MBA, Phyllis H. King,

Terraye M. Starr, Moua Yang,

Information Technology Specialists
Patricia Quinlisk, MD, MPH
Patrick L. Remington, MD, MPH
Carlos Roig, MS, MA
William Schaffner, MD
Morgan Bobb Swanson, BS 
TABLE 1. Universal hepatitis C testing programs at four urban emergency departments (EDs) — Birmingham, Alabama; Oakland, California; Baltimore, Maryland; and Boston, Massachusetts, 2015-2017

\begin{tabular}{|c|c|c|}
\hline Study site & Study dates & Program overview \\
\hline $\begin{array}{l}\text { University of Alabama at Birmingham } \\
\text { Hospital, Birmingham, Alabama }\end{array}$ & $\begin{array}{l}\text { Oct } 15,2015- \\
\text { Feb } 15,2016\end{array}$ & $\begin{array}{l}\text { Opt-out, nurse-driven intervention using electronic EHR prompts, physician counseling for positive } \\
\text { results for anti-HCV during ED visit, or specimens for HCV RNA testing collected during visit for persons } \\
\text { with positive results for anti-HCV }\end{array}$ \\
\hline Highland Hospital, Oakland, California & $\begin{array}{l}\text { Oct 15, 2015- } \\
\text { Feb 15, } 2016\end{array}$ & $\begin{array}{l}\text { Opt-out, nurse-driven intervention using EHR prompts at triage, physician counseling for positive results } \\
\text { for anti-HCV during ED visit, or specimens for HCV RNA testing collected during visit for persons with } \\
\text { positive results for anti-HCV }\end{array}$ \\
\hline $\begin{array}{l}\text { Johns Hopkins Hospital, Baltimore, } \\
\text { Maryland }\end{array}$ & $\begin{array}{l}\text { May 1, 2016- } \\
\text { Jul 31, 2016* }\end{array}$ & $\begin{array}{l}\text { Opt-out, triage nurse-driven intervention using EHR prompts, HCV program staff members informing and } \\
\text { consulting positive result for anti-HCV at callback after ED visit, or diagnostic HCV RNA testing at } \\
\text { callback after the visit for persons with positive results for anti-HCV }\end{array}$ \\
\hline $\begin{array}{l}\text { Boston University Medical Center, } \\
\text { Boston, Massachusetts }\end{array}$ & $\begin{array}{l}\text { Nov 2, 2016- } \\
\text { Feb 28, 2017 }\end{array}$ & $\begin{array}{l}\text { Opt-out, EHR-driven intervention using an EHR clinical decision support tool for all ED patients } \\
\text { undergoing phlebotomy, with reflex HCV RNA testing for persons with positive results for anti-HCV }\end{array}$ \\
\hline
\end{tabular}

Abbreviations: anti-HCV = HCV antibody; $\mathrm{EHR}=$ electronic health record; $\mathrm{HCV}=$ hepatitis $\mathrm{C}$ virus.

* Limited to a 3-month testing period because of programmatic changes occurring during the observation period.

TABLE 2. Universal hepatitis C testing results at four urban emergency departments (EDs) - Birmingham, Alabama; Oakland, California; Baltimore, Maryland; and Boston, Massachusetts, 2015-2017

\begin{tabular}{|c|c|c|c|c|c|}
\hline \multirow[b]{2}{*}{ Client and testing characteristic } & \multicolumn{5}{|c|}{ Study sites and dates } \\
\hline & $\begin{array}{c}\text { University of Alabama at } \\
\text { Birmingham Hospital, } \\
\text { Birmingham, Alabama } \\
\text { Oct 15, 2015- } \\
\text { Feb 15, } 2016\end{array}$ & $\begin{array}{l}\text { Highland Hospital, } \\
\text { Oakland, California } \\
\text { Oct 15, 2015- } \\
\text { Feb 15, } 2016\end{array}$ & $\begin{array}{l}\text { Johns Hopkins Hospital, } \\
\text { Baltimore, Maryland } \\
\text { May 1, 2016- } \\
\text { Jul 31, 2016* }\end{array}$ & $\begin{array}{c}\text { Boston University } \\
\text { Medical Center, } \\
\text { Boston, Massachusetts } \\
\text { Nov 2, 2016- } \\
\text { Feb 28, 2017 }\end{array}$ & All sites \\
\hline Unique ED visitors & 18,916 & 18,272 & 13,069 & 26,870 & 77,127 \\
\hline Patients eligible for hepatitis $C$ testing & 13,999 & 9,585 & 7,639 & 12,284 & $43,507^{\dagger}$ \\
\hline Anti-HCV tests performed & 5,973 & 2,900 & 1,638 & 3,741 & $14,252^{\S}$ \\
\hline Total anti-HCV positive tests (\%) & $459(7.7)$ & $166(5.7)$ & $120(7.3)$ & $570(15.2)$ & $1,315(9.2)$ \\
\hline $\begin{array}{l}\text { Adults born } 1945-1965, \text { positive test } \\
\text { results for anti-HCV/anti-HCV tests (\%) }\end{array}$ & $232 / 2,205(10.5)$ & $98 / 713(13.7)$ & $69 / 437(15.8)$ & $288 / 1,585(18.2)$ & $687 / 4,940(13.9)$ \\
\hline $\begin{array}{l}\text { Born after 1965, positive test results } \\
\text { for anti-HCV/anti-HCV tests (\%) }\end{array}$ & $227 / 3,768(6.0)$ & $68 / 2,187(3.1)$ & $51 / 1,201(4.2 \%)$ & $282 / 2,156(13.1)$ & $628 / 9,312(6.7)$ \\
\hline Total HCV RNA tests performed (\%) & $398(86.9)$ & $125(75.3)$ & $38(31.6)$ & $557(97.7)$ & $1,118(85)$ \\
\hline $\begin{array}{l}\text { Total current HCV infections (positive } \\
\text { test results for HCV RNA) (\%) }\end{array}$ & $252(63.3)$ & $79(63.2)$ & $27(71.1)$ & $335(60.1)$ & $693(62.0)$ \\
\hline $\begin{array}{l}\text { Estimated prevalence of positive } \\
\text { results for HCV RNA (\%) }\end{array}$ & 4.9 & 3.6 & 5.2 & 9.1 & 5.7 \\
\hline $\begin{array}{l}\text { State and national estimated } \\
\text { prevalence of positive results for HCV } \\
\text { RNA, \% }\end{array}$ & Alabama, 0.85 & California, 1.25 & Maryland, 1.00 & Massachusetts, 0.85 & National, 0.93 \\
\hline
\end{tabular}

Abbreviations: anti-HCV $=\mathrm{HCV}$ antibody; $\mathrm{EHR}=$ electronic health record; $\mathrm{HCV}=$ hepatitis $\mathrm{C}$ virus.

* Limited to a 3-month testing period because of programmatic changes occurring during the observation period.

† Born after 1944, aged $\geq 18$ years, medically or surgically stable, and no self-reported history of prior HCV infection.

$\S$ Reasons testing not performed included that the patient declined testing or venipuncture was not performed because no diagnostic tests requiring venipuncture were ordered by the ED provider.

blacks $(16.0 \%)$ than among whites $(12.2 \%)(\mathrm{p}<0.001)$. In contrast, overall prevalence of positive results for anti-HCV among persons born after 1965 was higher among whites $(15.3 \%)$ than among blacks $(3.2 \%)(\mathrm{p}<0.001)$. Significant differences in positive results for anti-HCV were identified among ED sites regarding race/ethnicity for both birth cohorts. Positive results for anti-HCV among whites born after 1965 was higher among patients evaluated at the University of Alabama at Birmingham (11.7\%), Johns Hopkins (11.8\%), and Boston University (30.1\%) sites than among those evaluated at Highland Hospital (3.2\%).
Among persons born during 1945-1965, and those born after 1965, prevalence of positive results for anti-HCV was significantly higher among men (18.9\% and $8.7 \%$, respectively), than among women $(8.3 \%$ and $5.1 \%$, respectively) $(\mathrm{p}<0.001)$. No statistically significant differences were identified in positive results for anti-HCV by sex among ED sites for either birth cohort (Table 3).

Prevalence of positive results for anti-HCV was higher among Medicaid or other public insurance recipients, persons with other or missing insurance information, and Medicare recipients, than among commercially insured persons in both the 1945-1965 birth cohort $(17.7 \%, 14.1 \%$, and $13.6 \%$, 
TABLE 3. Prevalence of positive results for hepatitis $C$ virus antibody (anti-HCV) and prevalence differences, by study site and patient characteristics - Birmingham, Alabama; Oakland, California; Baltimore, Maryland; and Boston, Massachusetts, 2015-2017

\begin{tabular}{|c|c|c|c|c|c|c|c|c|c|c|}
\hline \multirow[b]{2}{*}{ Characteristic } & \multicolumn{2}{|c|}{ All sites } & \multicolumn{2}{|c|}{$\begin{array}{c}\text { University of Alabama at } \\
\text { Birmingham Hospital, } \\
\text { Birmingham, Alabama }\end{array}$} & \multicolumn{2}{|c|}{$\begin{array}{l}\text { Highland Hospital, } \\
\text { Oakland, California }\end{array}$} & \multicolumn{2}{|c|}{$\begin{array}{l}\text { Johns Hopkins Hospital, } \\
\text { Baltimore, Maryland }\end{array}$} & \multicolumn{2}{|c|}{$\begin{array}{c}\text { Boston University } \\
\text { Medical Center, } \\
\text { Boston, Massachusetts }\end{array}$} \\
\hline & $\begin{array}{c}\text { Total no. } \\
\text { (\% positive } \\
\text { test results } \\
\text { for anti-HCV) }\end{array}$ & $\begin{array}{c}\text { Prevalence } \\
\text { difference } \\
(95 \% \mathrm{Cl})^{*}\end{array}$ & $\begin{array}{c}\text { Total no. } \\
\text { (\% positive } \\
\text { test results } \\
\text { for anti-HCV) }\end{array}$ & $\begin{array}{l}\text { Prevalence } \\
\text { difference } \\
(95 \% \mathrm{Cl})^{*}\end{array}$ & $\begin{array}{c}\text { Total no. } \\
\text { (\% positive } \\
\text { test results } \\
\text { for anti-HCV) }\end{array}$ & $\begin{array}{l}\text { Prevalence } \\
\text { difference } \\
(95 \% \mathrm{CI})^{*}\end{array}$ & $\begin{array}{c}\text { Total no. } \\
\text { (\% positive } \\
\text { test results } \\
\text { for anti-HCV) }\end{array}$ & $\begin{array}{l}\text { Prevalence } \\
\text { difference } \\
(95 \% \mathrm{Cl})^{*}\end{array}$ & $\begin{array}{c}\text { Total no. } \\
\text { (\% positive } \\
\text { test results } \\
\text { for anti-HCV) }\end{array}$ & $\begin{array}{c}\text { Prevalence } \\
\text { difference } \\
(95 \% \mathrm{Cl})^{*}\end{array}$ \\
\hline \multicolumn{11}{|c|}{ Born during 1945-1965 } \\
\hline \multicolumn{11}{|l|}{ Sex } \\
\hline Women & 2,325 (8.3) & Referent & $1,100(6.2)$ & Referent & $298(10.1)$ & Referent & $190(7.9)$ & Referent & $737(11.0)$ & Referent \\
\hline Men & $2,615(18.9)$ & $\begin{array}{l}10.5 \text { ( } 8.6 \text { to } \\
12.4)\end{array}$ & $1,105(14.8)$ & $\begin{array}{c}8.7(6.3 \text { to } \\
11.2)\end{array}$ & $415(16.4)$ & $\begin{array}{c}6.3(1.3 \text { to } \\
11.9)\end{array}$ & 247 (21.9) & $\begin{array}{l}14.0(8.2 \text { to } \\
20.9)\end{array}$ & $848(24.4)$ & $\begin{array}{c}13.4(9.7 \text { to } \\
16.7)\end{array}$ \\
\hline \multicolumn{11}{|l|}{ Race/Ethnicity } \\
\hline White, NH & $1,695(12.2)$ & $\begin{array}{c}-3.8(-5.8 \text { to } \\
1.6)\end{array}$ & $1,058(9.5)$ & $\begin{array}{c}-2.4(-5.0 \text { to } \\
0.4)\end{array}$ & $92(13.0)$ & $\begin{array}{c}-4.3(-11.1 \text { to } \\
5.2)\end{array}$ & $121(3.3)$ & $\begin{array}{l}-19.2(-24.8 \\
\text { to } 13.6)\end{array}$ & $424(21.2)$ & $\begin{array}{l}2.5(-2.1 \text { to } \\
7.2)\end{array}$ \\
\hline Black, NH & $2,534(16.0)$ & Referent & $1,093(11.8)$ & Referent & $358(17.3)$ & Referent & $284(22.5)$ & Referent & $799(18.8)$ & Referent \\
\hline Other/Missing & $711(10.7)$ & $\begin{array}{c}-5.3(-7.9 \text { to } \\
-2.5)\end{array}$ & $54(5.6)$ & $\begin{array}{c}-6.2(-11.1 \text { to } \\
1.4)\end{array}$ & $263(9.1)$ & $\begin{array}{c}-8.2(-13.3 \text { to } \\
-2.4)\end{array}$ & $32(3.1)$ & $\begin{array}{l}-19.4(-26.0 \\
\text { to }-10.9)\end{array}$ & $362(13.3)$ & $\begin{array}{c}-5.5(-9.5 \text { to } \\
-0.8)\end{array}$ \\
\hline \multicolumn{11}{|l|}{ Insurance type } \\
\hline Commercial & $1,138(8.4)$ & $\begin{array}{c}-9.3(-11.8 \text { to } \\
-7.2)\end{array}$ & $562(4.8)$ & $\begin{array}{c}-12.1(-16.1 \\
\text { to }-8.1)\end{array}$ & $23(13.0)$ & $\begin{array}{l}0.2(-11.7 \text { to } \\
19.8)\end{array}$ & 269 (11.9) & $\begin{array}{c}-15.6(-30.4 \\
\text { to } 1.4)\end{array}$ & $284(12.0)$ & $\begin{array}{c}-8.7(-13.5 \text { to } \\
-3.8)\end{array}$ \\
\hline Medicare & $1,482(13.6)$ & $\begin{array}{c}-4.1(-6.7 \text { to } \\
-1.8)\end{array}$ & $844(9.5)$ & $\begin{array}{c}-7.4(-11.6 \text { to } \\
-3.4)\end{array}$ & $115(19.1)$ & $\begin{array}{c}6.3(-1.8 \text { to } \\
14.1)\end{array}$ & $79(19.0)$ & $\begin{array}{c}-8.5(-26.6 \text { to } \\
6.8)\end{array}$ & $444(19.1)$ & $\begin{array}{c}-1.5(-6.1 \text { to } \\
3.0)\end{array}$ \\
\hline $\begin{array}{l}\text { Medicaid/ } \\
\text { Publicly funded }\end{array}$ & $1,702(17.7)$ & Referent & $420(16.9)$ & Referent & 467 (12.9) & Referent & $40(27.5)$ & Referent & $775(20.7)$ & Referent \\
\hline Other/Missing & $618(14.1)$ & $\begin{array}{c}-3.7(-6.9 \text { to } \\
-0.2)\end{array}$ & $379(14.3)$ & $\begin{array}{c}-2.7(-7.5 \text { to } \\
2.7)\end{array}$ & $108(12.0)$ & $\begin{array}{c}-0.8(-7.6 \text { to } \\
6.5)\end{array}$ & $49(22.5)$ & $\begin{array}{c}-5.1(-23.9 \text { to } \\
13.0)\end{array}$ & $82(11.0)$ & $\begin{array}{c}-9.7(-16.9 \text { to } \\
-1.8)\end{array}$ \\
\hline \multicolumn{11}{|l|}{ Born after 1965} \\
\hline \multicolumn{11}{|l|}{ Sex } \\
\hline Women & $5,119(5.1)$ & Referent & $2,149(4.1)$ & Referent & $1,121(2.8)$ & Referent & $680(3.5)$ & Referent & $1,169(10.2)$ & Referent \\
\hline Men & 4,193 (8.7) & 3.6 (2.5 to 4.7$)$ & $1,619(8.5)$ & $4.4(2.8$ to 6.0$)$ & $1,066(3.5)$ & $\begin{array}{l}0.7(-0.7 \text { to } \\
2.2)\end{array}$ & $521(5.2)$ & $\begin{array}{c}1.7(-0.6 \text { to } \\
4.0)\end{array}$ & $987(16.5)$ & 6.3 (3.6 to 9.5 ) \\
\hline \multicolumn{11}{|l|}{ Race/Ethnicity } \\
\hline White, $\mathrm{NH}$ & $2,623(15.3)$ & $\begin{array}{c}12.2(10.6 \text { to } \\
13.6)\end{array}$ & $1,554(11.7)$ & $\begin{array}{c}9.7(8.1 \text { to } \\
11.6)\end{array}$ & $185(3.2)$ & $\begin{array}{c}-0.2(-2.8 \text { to } \\
2.4)\end{array}$ & $280(11.8)$ & $\begin{array}{c}9.7(6.1 \text { to } \\
13.8)\end{array}$ & $604(30.1)$ & $\begin{array}{c}23.9(19.9 \text { to } \\
27.7)\end{array}$ \\
\hline Black, NH & $4,711(3.2)$ & Referent & $2,063(2.0)$ & Referent & $867(3.5)$ & Referent & $780(2.1)$ & Referent & $1,001(6.2)$ & Referent \\
\hline Other/Missing & $1,978(3.9)$ & $\begin{array}{c}0.7(-0.2 \text { to } \\
1.7)\end{array}$ & $151(3.3)$ & $\begin{array}{c}1.3(-1.0 \text { to } \\
5.0)\end{array}$ & $1,135(2.8)$ & $\begin{array}{c}-0.6(-2.4 \text { to } \\
7.6)\end{array}$ & $141(1.4)$ & $\begin{array}{c}-0.6(-2.3 \text { to } \\
2.2)\end{array}$ & 551 (6.9) & $\begin{array}{l}0.7(-1.8 \text { to } \\
3.5)\end{array}$ \\
\hline \multicolumn{11}{|l|}{ Insurance type } \\
\hline Commercial & $2,370(3.0)$ & $\begin{array}{c}-5.6(-6.8 \text { to } \\
-4.5)\end{array}$ & $1,065(2.2)$ & $\begin{array}{c}-3.0(-4.7 \text { to } \\
-1.3)\end{array}$ & $94(3.2)$ & $\begin{array}{c}-0.0(-3.0 \text { to } \\
4.1)\end{array}$ & $800(3.4)$ & $\begin{array}{c}-7.0(-13.0 \text { to } \\
-2.1)\end{array}$ & $411(4.4)$ & $\begin{array}{c}-12.1(-15.2 \\
\text { to }-9.5)\end{array}$ \\
\hline Medicare & $634(9.0)$ & $\begin{array}{l}0.4(-1.8 \text { to } \\
2.8)\end{array}$ & $359(6.4)$ & $\begin{array}{c}1.3(-1.5 \text { to } \\
4.3)\end{array}$ & $48(4.2)$ & $\begin{array}{c}0.9 \text { (-3.6 to } \\
8.3)\end{array}$ & $57(1.8)$ & $\begin{array}{c}-8.6(-15.3 \text { to } \\
-2.0)\end{array}$ & $170(18.2)$ & $\begin{array}{c}1.7(-3.7 \text { to } \\
8.7)\end{array}$ \\
\hline $\begin{array}{l}\text { Medicaid/ } \\
\text { Publicly funded }\end{array}$ & $3,944(8.6)$ & Referent & $935(5.1)$ & Referent & $1,486(3.2)$ & Referent & $135(10.4)$ & Referent & $1,388(16.5)$ & Referent \\
\hline Other/Missing & $2,364(6.8)$ & $\begin{array}{c}-1.8(-3.1 \text { to } \\
-0.4)\end{array}$ & $1,409(9.4)$ & 4.3 (2.2 to 6.5$)$ & $559(2.7)$ & $\begin{array}{c}-0.5(-2.0 \text { to } \\
1.2)\end{array}$ & $209(4.3)$ & $\begin{array}{c}-6.1(-12.4 \text { to } \\
-0.9)\end{array}$ & $187(2.1)$ & $\begin{array}{c}-14.4(-16.9 \text { to } \\
-11.5)\end{array}$ \\
\hline
\end{tabular}

Abbreviations: $\mathrm{Cl}=$ confidence interval, $\mathrm{NH}=$ non-Hispanic.

* Bias-corrected $95 \%$ Cls for prevalence differences calculated by using 1,000 bootstrap replicates.

respectively, versus $8.4 \% ; \mathrm{p}<0.001)$ and persons born after 1965 $(8.6 \%, 6.8 \%$, and $9.0 \%$, respectively, versus $3.0 \%$; $\mathrm{p}<0.001)$.

\section{Discussion}

Opt-out, universal HCV screening in four geographically diverse, urban EDs identified a high prevalence of previously unrecognized positive results for anti-HCV in approximately one of every $11(9.2 \%)$ adult patients tested. Prevalence of positive results for HCV RNA at the combined ED sites was $5.7 \%$, which was substantially higher than the estimated overall U.S. prevalence of positive results for HCV RNA of $0.95 \%$ (8). At the state level, ED prevalence of positive results for HCV RNA ranged from three to fivefold higher than the upper-estimated prevalence of positive results for HCV RNA rates in each respective state (8). These findings demonstrate the high yield and potential impact of an ED-based opt-out, universal testing strategy.

Considering that the advent of HCV curative therapies, potential exists to eliminate HCV infection from U.S. communities. For this reason, identification of persons unaware of their 


\section{Summary}

What is already known about this topic?

Targeted testing for hepatitis C virus (HCV) infection in emergency departments (EDs) has been demonstrated to be a high-yield and effective intervention for identifying previously unrecognized infections, especially among persons born during 1945-1965.

What is added by this report?

Opt-out, universal HCV screening in EDs identified that nearly half (47.5\%) of infections were among persons born after 1965.

What are the implications for public health practice?

Opt-out, universal screening in EDs can identify a larger number of previously unrecognized HCV infections, especially among persons born after 1965. ED-based opt-out, universal hepatitis C screening can be vital in combating and surveilling the interrelated epidemics of opioid overdose and bloodborne viral infections through harm-reduction interventions and navigation to HCV treatment.

$\mathrm{HCV}$ infection has become a public health priority. Because of the increasing incidence of HCV infection among persons who inject drugs, testing and treatment of this population is needed for both infection prevention and for ending the HCV infection epidemic. Although recent studies of ED-based, targeted hepatitis $\mathrm{C}$ testing have highlighted the high prevalence of positive results for anti-HCV among the 1945-1965 birth cohort (10.3\%-11.6\%), ED-based programs have been challenged to systematically identify and test an increasing number of younger persons who inject drugs $(5,6,9,10)$.

Although three quarters of HCV infections in the United States are among persons born during 1945-1965, this study demonstrates that nearly half of all persons reactive to antiHCV identified in EDs were among the cohort born after 1965. This finding is consistent with two recent ED studies, both of which reported that an ED-based 1945-1965 birth cohort strategy alone would fail to identify half of persons with HCV infection $(8,9)$. Most striking in the current study was the high prevalence of positive results for anti-HCV (6.7\%) noted among the younger population, driven by the high prevalence of positive results for anti-HCV among whites (15.3\%). Although behavioral risk factors could not be confirmed for this study, this racial/ethnic difference is consistent with the epidemiology of HCV infection and injection drug use behavior (2).

By leveraging lessons learned from national HIV testing efforts, opt-out, universal HCV screening might improve rates of hepatitis $\mathrm{C}$ testing among populations at high risk by reducing patient and provider stigma associated with identification of hepatitis $\mathrm{C}$ behavioral risks as a prerequisite for testing. In addition, the opt-out, universal screening strategy that requires less risk behavior questioning is easier to operationalize in EDs challenged by competing priorities.

Although both targeted and opt-out, universal ED-based hepatitis $\mathrm{C}$ testing strategies are effective at identifying previously unrecognized HCV infections, reimbursement for testing and challenging HCV infection care navigation remain crucial barriers. A 2014 decision from the U.S. Department of Health and Human Services and Centers for Medicare \& Medicaid Services precluding EDs from reimbursement for hepatitis $\mathrm{C}$ testing might be limiting adoption of any systematic hepatitis $\mathrm{C}$ testing in the majority of EDs. ${ }^{\dagger}$ In addition, the high number of persons with HCV infection identified in the ED setting challenges $\mathrm{HCV}$ navigation programs and requires robust support to effectively direct persons who test positive to HCV treatment and other necessary health services, including primary care, social services, and substance use treatment.

The findings in this study are subject to at least three limitations. First, identifying previously unrecognized HCV infection is limited by the patient's recall of their prior HCV infection history and is therefore subject to bias. Second, 29,255 persons identified as being eligible for hepatitis $C$ testing in the study EDs were not tested because a venipuncture was not performed for other diagnostics ordered by the ED provider during the visit, a prior HCV test result was identified in the electronic health record, or the patient declined to be tested. This is consistent with previously reported findings from ED-based targeted hepatitis $\mathrm{C}$ testing $(5,6)$, and bias was not introduced toward testing persons appearing to be at high risk. Finally, study findings are limited to four geographically diverse, urban academic EDs, and might not apply to all U.S. geographic areas or in nonurban or community EDs.

The high prevalence of HCV infection identified among persons born after 1965 as well as those born during 1945-1965 supports continued assessment of ED-based hepatitis C testing, as well as an opt-out, universal screening strategy among similar high-prevalence health care venues. Given the high prevalence of positive results for HCV RNA identified among a younger, predominately white cohort known to be disproportionately affected by the opioid crisis, ED-based opt-out, universal

\footnotetext{
${ }^{\dagger}$ https://www.cms.gov/medicare-coverage-database/details/nca-decision-memo. aspx?NCAId=272.
} 
HCV screening might play an important role in surveillance and combat of interrelated epidemics of opioid overdose and bloodborne viral infections through harm-reduction interventions and navigation to HCV treatment.

Corresponding author: William W. Thompson,wct2@cdc.gov, 404-226-8428.

${ }^{1}$ Department of Emergency Medicine, University of Mississippi Medical Center, Jackson, Mississippi; ${ }^{2}$ Department of Emergency Medicine, Alameda Health System-Highland Hospital, Oakland, California; ${ }^{3}$ Department of Emergency Medicine, Johns Hopkins School of Medicine, Baltimore, Maryland; ${ }^{4}$ Department of Medicine, University of Alabama School of Medicine, Birmingham, Alabama; ${ }^{5}$ Department of Learning Health Sciences, University of Michigan Medical School, Ann Arbor, Michigan; ${ }^{6}$ Institute for Healthcare Policy and Innovation, University of Michigan, Ann Arbor, Michigan; ${ }^{7}$ Department of Emergency Medicine, University of Alabama at Birmingham, Birmingham, Alabama; ${ }^{8}$ Department of Emergency Medicine, Boston University, Boston, Massachusetts; ${ }^{9}$ Division of Viral Hepatitis, National Center for HIV/AIDS, Viral Hepatitis, STD, and TB Prevention, CDC.

All authors have completed and submitted the International Committee of Medical Journal Editors form for disclosure of potential conflicts of interest. Ricardo Franco reports grants and personal fees from Gilead during the conduct of the study, and personal fees from Abbvie and grants from Merck outside the submitted work. James Galbraith reports grants from Gilead Sciences outside the submitted work. Yu-Hsiang Hsieh reports grants from Gilead Sciences HIV FOCUS program during the conduct of the study. Elissa SchechterPerkins reports grants from Gilead Sciences during the conduct of the study. Joel Rodgers reports grants from Gilead Sciences during the conduct of the study. Richard Rothman reports grants from Gilead FOCUS during the conduct of the study. Douglas White reports grants from Gilead Sciences during the conduct of the study. No other potential conflicts of interest were disclosed.

\section{References}

1. Smith BD, Morgan RL, Beckett GA, et al. Recommendations for the identification of chronic hepatitis $\mathrm{C}$ virus infection among persons born during 1945-1965. MMWR Recomm Rep 2012;61(No. RR-4).

2. Scholl L, Seth P, Kariisa M, Wilson N, Baldwin G. Drug and opioid-involved overdose deaths_-United States, 2013-2017. MMWR Morb Mortal Wkly Rep 2018;67:1419-27. https://doi.org/10.15585/mmwr.mm675152e1

3. Suryaprasad AG, White JZ, Xu F, et al. Emerging epidemic of hepatitis $\mathrm{C}$ virus infections among young nonurban persons who inject drugs in the United States, 2006-2012. Clin Infect Dis 2014;59:1411-9. https:// doi.org/10.1093/cid/ciu643

4. Van Handel MM, Rose CE, Hallisey EJ, et al. County-level vulnerability assessment for rapid dissemination of HIV or HCV infections among persons who inject drugs, United States. J Acquir Immune Defic Syndr 2016;73:323-31. https://doi.org/10.1097/QAI.0000000000001098

5. Galbraith JW, Franco RA, Donnelly JP, et al. Unrecognized chronic hepatitis $\mathrm{C}$ virus infection among baby boomers in the emergency department. Hepatology 2015;61:776-82. https://doi.org/10.1002/hep.27410

6. White DAE, Anderson ES, Pfeil SK, Trivedi TK, Alter HJ. Results of a rapid hepatitis $\mathrm{C}$ virus screening and diagnostic testing program in an urban emergency department. Ann Emerg Med 2016;67:119-28. https://doi.org/10.1016/j.annemergmed.2015.06.023

7. Schillie S, Wester C, Osborne M, Wesolowski L, Ryerson AB. CDC recommendations for hepatitis $\mathrm{C}$ screening among adults-United States, 2020. MMWR Recomm Rep 2020;69(No. RR-2). https://doi. org/10.15585/mmwr.rr6902a1

8. Rosenberg ES, Rosenthal EM, Hall EW, et al. Prevalence of hepatitis C virus infection in US states and the District of Columbia, 2013 to 2016. JAMA Netw Open 2018;1:e186371-14. https://doi.org/10.1001/ jamanetworkopen.2018.6371

9. Merchant RC, Baird JR, Liu T, Taylor LE. HCV among The Miriam Hospital and Rhode Island Hospital adult ED patients. R I Med J (2013) 2014;97:35-9.

10. Hsieh Y-H, Rothman RE, Laeyendecker OB, et al. Evaluation of the Centers for Disease Control and Prevention recommendations for hepatitis $\mathrm{C}$ virus testing in an urban emergency department. Clin Infect Dis 2016;62:1059-65. https://doi.org/10.1093/cid/ciw074 